\title{
Post-transplant immunotherapy with WT1-specific CTLs for high-risk acute myelogenous leukemia: a prospective clinical phase I/II trial
}

\author{
Hee-Je Kim ${ }^{1} \cdot$ Hyun-Jung Sohn ${ }^{2} \cdot$ Jung-A Hong ${ }^{2} \cdot$ Hyun-Joo Lee ${ }^{2} \cdot$ Dae-Hee Sohn ${ }^{3} \cdot$ Chang-Ae Shin $^{3} \cdot$ \\ Hyun-II Cho $\mathbb{D}^{2} \cdot$ Woo-Sung Min ${ }^{1} \cdot$ Tai-Gyu Kim ${ }^{2,3}$
}

Received: 20 September 2018 / Accepted: 28 September 2018 / Published online: 8 November 2018

(c) The Author(s) 2018. This article is published with open access

Wilms' tumor antigen 1 (WT1) is more abundant in leukemic cells than in normal hematopoietic cells. Quantitative assessment of WT1 gene transcript abundance by real-time quantitative PCR (RQ-PCR) has been shown to be useful for predicting clinical outcome and prognosis in acute myelogenous leukemia (AML), and for detecting minimal residual disease (MRD) [1-3]. In addition, the expansion of WT1-specific $\mathrm{CD}^{+} \mathrm{T}$ cells was correlated with graftversus-leukemia (GVL) effect in 10 subjects with acute lymphoblastic leukemia [4]. Autologous vaccination of AML patients with WT1 peptide or with full-length WT1 mRNA-electroporated dendritic cells (DCs) showed immunogenic and anti-leukemic activity, as evidenced by the conversion of partial remission and the induction of molecular remission [5, 6]. Adoptive transfer of WT1-specific $\mathrm{T}$ cells mediated antileukemic activity and persistence in relapsed or high-risk leukemia patients after hematopoietic stem cell transplantation (HSCT) [7, 8]. In the present prospective clinical phase I/II study with long-term follow-up, we demonstrated that adoptive transfer of WT1specific cytotoxic T cells (WT1-CTLs) generated in vitro from donor-derived DCs transduced with an adenoviral vector expressing human WT1 (Adv-WT1) is a feasible

Electronic supplementary material The online version of this article (https://doi.org/10.1038/s41409-018-0383-2) contains supplementary material, which is available to authorized users.

$\triangle$ Tai-Gyu Kim

kimtg@catholic.ac.kr

1 Leukemia Research Institute, Seoul St. Mary's Hematology Hospital, College of Medicine, The Catholic University of Korea, Seoul, Korea

2 Catholic Hematopoietic Stem Cell Bank, College of Medicine, The Catholic University of Korea, Seoul, Korea

3 Department of Microbiology, College of Medicine, The Catholic University of Korea, Seoul, Korea therapeutic tool with acceptable safety that can induce an optimistic long-term clinical response accompanied by $\mathrm{T}$ cell responses against WT1 in adult patients with relapse high-risk AML after allogeneic HSCT.

A total of 13 newly diagnosed adult patients treated for AML between 2007 and 2008 in the Catholic Blood and Marrow Transplantation Center were considered eligible for this study if they had a human leukocyte antigen (HLA)identical sibling donor. The trial included five male and five female patients, with a median age of 40 years (range, 2849 years), who were categorized as high-risk AML mainly based on the higher expression levels of WT1 at initial diagnosis [2, 9] and received an allogeneic sibling donor HSCT followed by anti-leukemic WT1-CTLs infusion (Table 1). For in vitro induction of WT1-CTLs from healthy donors, monocyte-derived DCs were transduced with an adenoviral vector for WT1 expression. The proportion of $\mathrm{CD}^{+}$and $\mathrm{CD}^{+} \mathrm{T}$ cells in the generated CTLs was $65.9 \pm$ $15 \%$ and $25.9 \pm 12 \%$ and the frequencies of WT1-specific IFN- $\gamma$-secreting $\mathrm{CD}^{+}$and $\mathrm{CD}^{+}{ }^{+} \mathrm{T}$ cells were 147.3 and 305 per $10^{6}$ cells, respectively. Beginning on $\mathrm{D}+35$ posttransplantation, $4 \times 10^{7}$ WT1-CTLs were infused four consecutive times at 1 -week intervals in patients without moderate to severe acute graft-versus-host-disease (GVHD). Every 1-3 months after the CTLs infusion, and for at least 1 year post transplantation, we serially monitored the clinical status, and the peripheral blood lymphocyte subpopulations using flow cytometry, the in vitro activity of interferongamma (IFN- $\gamma$ ) by enzyme-linked immunospot (ELISPOT) assay, and WT1 expression levels by RQ-PCR.

All patients were successfully engrafted; however, three of them (UPN 7, 8, and 9) died due to relapse after transplant. One of the two patients with treatment-related mortality (TRM) (UPN 2) died due to septic pneumonia and cytomegalovirus (CMV) disease in the gut combined with extensivetype GVHD at 1 year, and the other patient (UPN 6) died due to rapidly progressing gram-negative sepsis and a disseminated herpes simplex viral infection at 10 months after 


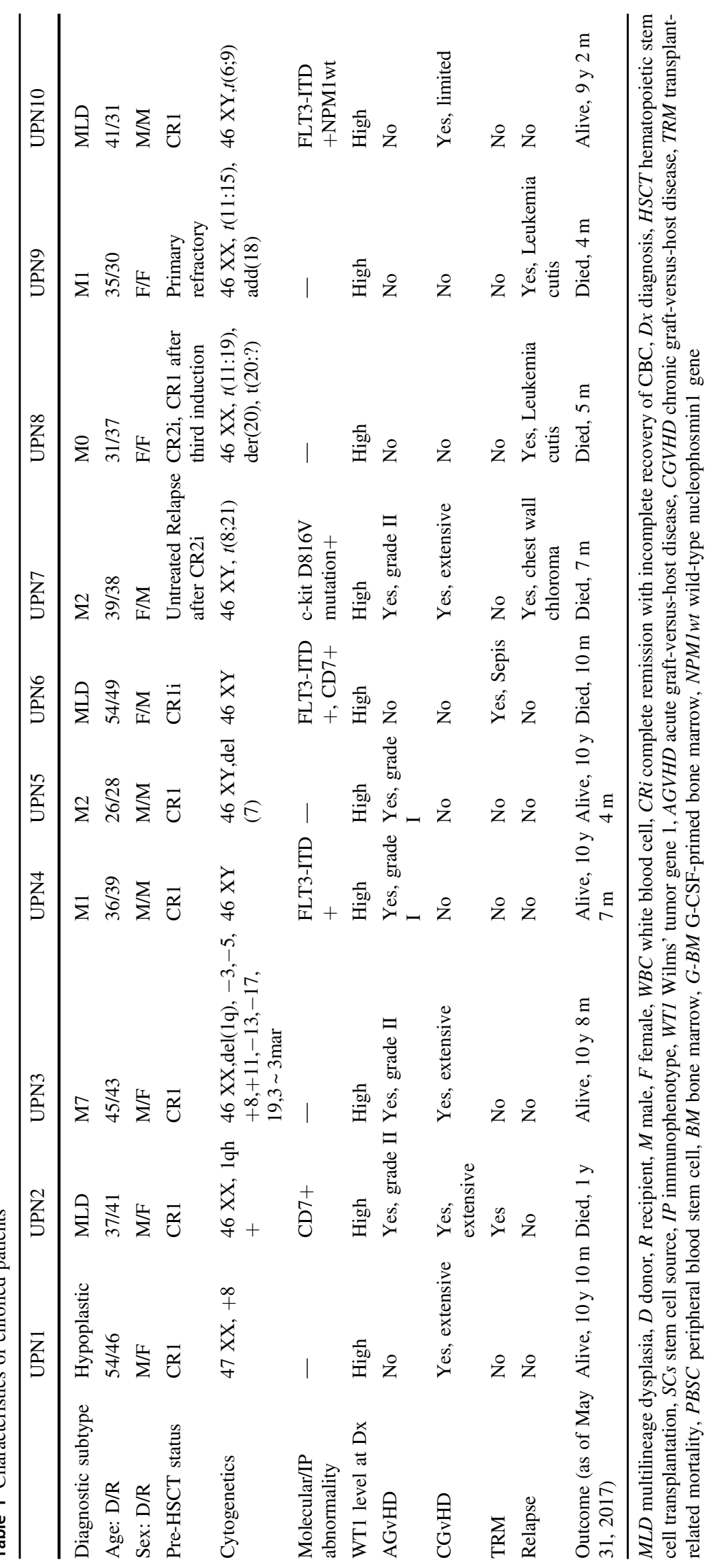


transplant. However, these two patients had no evidence of relapse. The five other patients are alive, at a median followup of 127 months (range, 102-130 years), and the 8-year event-free survival (EFS) rate was $50 \%$. In our previous studies, the long-term survival rates for high-risk patients who received allogeneic stem cell transplantation in CR1 without any adoptive immunotherapy is less likely around $30 \%$ [9, 10]. Among patients with complete remission 1 (CR1) preHSCT status, the EFS rate was $71.4 \%$. These findings suggest that WTI-CTLs administration could induce prolonged remission only in patients without MRD, but not prevent the rapid proliferation of leukemic stem/progenitor cells even after transient hematological CR conditions established by myeloablative conditioning.

Despite the beneficial potential of WT1-CTLs therapy following allogeneic HSCT, it is necessary to consider the possibility of inducing severe chronic GVHD related to CTLs infusion. In the study, 4 out of $10(40 \%)$ patients developed extensive type of chronic GVHD. As depicted in Table 1, UPN1 showed de novo type of chronic GVHD with skin and liver involvement and a typical manifestation of sicca 4 months after HSCT. UPN2 also showed a persistent type of chronic GVHD starting from grade I acute GVHD just early after the 3rd infusion of WT1-CTLs. UPN3 and UPN7 showed a multi-organ pattern of grade II acute GVHD involving the skin and gut after the final infusion of WTI-CTLs, and then progressed to extensive type of chronic GVHD until 6 months, 7 months after transplantation, respectively. Although, the precise causal relationship in association with the infused WTI-CTLs was not clear enough, patients having extensive type of chronic GVHD not in relapse were successfully manageable without any long-term sequelae, as shown in Table 1 . Further revelation to clarify the direct effect of infused WT1-CTLs on chronic GVHD is quite anticipated in the future study.

The results from the long-term monitoring of the five living patients showed individual differences in the frequencies of $W T 1$-specific $\mathrm{CD} 8^{+}$and $\mathrm{CD} 4^{+} \mathrm{T}$ cells and $W T 1$ expression levels in peripheral blood mononuclear cells (Supplementary Figure 1). In UPN 1, there were predominant strong-specific T-cell responses with mostly $\mathrm{CD}^{+}{ }^{+} \mathrm{T}$ cells following three peaks in WT1 expression. UPN 3 and UPN 4 showed mainly $\mathrm{CD}^{+}{ }^{+}$T-cell responses around a single peak of WT1 expression. Among the patients with relapse, UPN 8 showed an increased, sustained, strong T-cell response as WTI expression increased. Our data suggest that $W T 1$-specific T-cell activity increases in response to an increase in the amount of WT1 antigen expressed by the leukemic cells in the patients, and that $\mathrm{CD}^{+}{ }^{+} \mathrm{T}$ cells are as important as $\mathrm{CD} 8^{+} \mathrm{T}$ cells in inhibiting leukemia. Also, we measured the lymphocyte subpopulations in the patients' blood for 140 weeks after the first
WT1-CTLs infusion using multiparameter flow cytometry (MFC) (Supplement Figure 2). Various clinical features were observed in each patient and the clinical relevance of the prognosis was not observed. Supplementary Figure 1 has shown that WTI-CTLs is already present in some AML patients and dose not clearly demonstrate the persistence and efficacy of infused cells. But our previous pilot trial, we observed that frequencies of $\mathrm{CD}^{+} \mathrm{T}$ cells and $\mathrm{CD} 8^{+}$ $\mathrm{T}$ cells increased progressively during serial infusion of WT1-CTLs and the pattern persisted until 9 months together with specific T-cell responses maintained against $W T 1$ for more 2 years infusion [8]. In other previous study has shown that gene marking studies have been performed to identify cytotoxic T-cells infused after HSCT [11]. In this study, it was difficult to determine whether the engraftment and proliferation of infused cells. Therefore, further studies will be required to confirm the efficacy of infused donor cells by short tandem repeat (STR) test.

Taken together, despite the small number of patients enrolled in the study, this exploratory trial of WT1-CTLs after allogeneic HSCT for high-risk AML suggests the possibility of using this therapeutic strategy in combination with elective allogeneic or even autologous HSCT with WT1-CTL infusion. Generation of multi-antigen-specific $\mathrm{T}$ cells to enhance the GVL effect and prevent infection after allogeneic HSCT may be promising treatment in the near future, as well as the development of immunotherapy using T-cell receptor (TCR)-engineered T cells $[12,13]$.

\section{Compliance with ethical standards}

Conflict of interest The authors declare that they have no conflict of interest.

Open Access This article is licensed under a Creative Commons Attribution 4.0 International License, which permits use, sharing, adaptation, distribution and reproduction in any medium or format, as long as you give appropriate credit to the original author(s) and the source, provide a link to the Creative Commons license, and indicate if changes were made. The images or other third party material in this article are included in the article's Creative Commons license, unless indicated otherwise in a credit line to the material. If material is not included in the article's Creative Commons license and your intended use is not permitted by statutory regulation or exceeds the permitted use, you will need to obtain permission directly from the copyright holder. To view a copy of this license, visit http://creativecommons. org/licenses/by/4.0/.

\section{References}

1. Inoue $\mathrm{K}$, Sugiyama $\mathrm{H}$, Ogawa $\mathrm{H}$, Nakagawa $\mathrm{M}$, Yamagami $\mathrm{T}$, Miwa H, et al. WT1 as a new prognostic factor and a new marker for the detection of minimal residual disease in acute leukemia. Blood. 1994;84:3071-9. e-pub ahead of print 1994/11/01

2. Kim HJ, Choi EJ, Sohn HJ, Park SH, Min WS, Kim TG. Combinatorial molecular marker assays of WT1, survivin, and TERT at initial diagnosis of adult acute myeloid leukemia. Eur $\mathrm{J}$ 
Haematol. 2013;91:411-22. https://doi.org/10.1111/ejh.12167. epub ahead of print 2013/07/06.

3. Yoon JH, Kim HJ, Kwak DH, Park SS, Jeon YW, Lee SE, et al. High WT1 expression is an early predictor for relapse in patients with acute promyelocytic leukemia in first remission with negative PML-RARa after anthracycline-based chemotherapy: a singlecenter cohort study. J Hematol Oncol. 2017;10:30 https://doi.org/ 10.1186/s13045-017-0404-4. e-pub ahead of print 2017/01/25.

4. Rezvani K, Yong AS, Savani BN, Mielke S, Keyvanfar K, Gostick E, et al. Graft-versus-leukemia effects associated with detectable Wilms tumor-1 specific T lymphocytes after allogeneic stem-cell transplantation for acute lymphoblastic leukemia. Blood. 2007;110:1924-32. https://doi.org/10.1182/blood-2007-03-076844. e-pub ahead of print 2007/05/17.

5. Mailander V, Scheibenbogen C, Thiel E, Letsch A, Blau IW, Keilholz U. Complete remission in a patient with recurrent acute myeloid leukemia induced by vaccination with WT1 peptide in the absence of hematological or renal toxicity. Leukemia. 2004;18:165-6. https://doi.org/10.1038/sj.leu.2403186. e-pub ahead of print 2003/11/07.

6. Van Tendeloo VF, Van de Velde A, Van Driessche A, Cools N, Anguille S, Ladell K, et al. Induction of complete and molecular remissions in acute myeloid leukemia by Wilms' tumor 1 antigentargeted dendritic cell vaccination. Proc Natl Acad Sci USA. 2010;107:13824-9. https://doi.org/10.1073/pnas.1008051107. epub ahead of print 2010/07/16.

7. Chapuis AG, Ragnarsson GB, Nguyen HN, Chaney CN, Pufnock JS, Schmitt TM, et al. Transferred WT1-reactive CD8+T cells can mediate antileukemic activity and persist in post-transplant patients. Sci Transl Med. 2013;5:174ra127 https://doi.org/10. 1126/scitranslmed.3004916. e-pub ahead of print 2013/03/01.

8. Kim YJ, Cho SG, Lee S, Kim MS, Kim EK, Cho BS, et al. Potential role of adoptively transferred allogeneic WT1-specific $\mathrm{CD} 4+$ and $\mathrm{CD} 8+\mathrm{T}$ lymphocytes for the sustained remission of refractory AML. Bone Marrow Transplant. 2010;45:597-9. https://doi.org/10.1038/bmt.2009.191. e-pub ahead of print 2009/ $08 / 18$.

9. Yoon JH, Kim HJ, Shin SH, Yahng SA, Lee SE, Cho BS, et al. Serial measurement of WT1 expression and decrement ratio until hematopoietic cell transplantation as a marker of residual disease in patients with cytogenetically normal acute myelogenous leukemia. Biol Blood Marrow Transplant: J Am Soc Blood Marrow Transplant. 2013;19:958-66. https://doi.org/10.1016/j.bbmt.2013. 03.013. e-pub ahead of print 2013/04/02.

10. Yoon JH, Kim HJ, Shin SH, Lee SE, Cho BS, Eom KS. et al. Stratification of de novo adult acute myelogenous leukemia with adverse-risk karyotype: can we overcome the worse prognosis of adverse-risk group acute myelogenous leukemia with hematopoietic stem cell transplantation?. Biol Blood Marrow Transplant: J Am Soc Blood Marrow Transplant. 2014;20:80 88. https://doi.org/10.1016/j.bbmt.2013.10.015.e-pub ahead of print 2013/10/24.

11. Rooney CM, Smith CA, Ng CY, Loftin S, Li C, Krance RA, et al. Use of gene-modified virus-specific $\mathrm{T}$ lymphocytes to control Epstein-Barr-virus-related lymphoproliferation. Lancet. 1995;345: 9-13. e-pub ahead of print 1995/01/07.

12. Sohn HJ, Lee JY, Lee HJ, Sohn DH, Cho HI, Kim HJ, et al. Simultaneous in vitro generation of CD8 and CD4 T cells specific to three universal tumor associated antigens of WT1, survivin and TERT and adoptive $\mathrm{T}$ cell transfer for the treatment of acute myeloid leukemia. Oncotarget. 2017. e-pub ahead of print 2017/05/10; https://doi.org/10.18632/oncotarget. 17212.

13. Stauss HJ, Thomas S, Cesco-Gaspere M, Hart DP, Xue SA, Holler A, et al. WT1-specific T cell receptor gene therapy: improving TCR function in transduced T cells. Blood Cells Mol Dis. 2008;40:113-6. https://doi.org/10.1016/j.bcmd.2007.06. 018. e-pub ahead of print 2007/09/15. 